\title{
Factors Affecting the Earnings Management: The Case of Listed Firms in Vietnam
}

\author{
Hien Thu BUI ${ }^{1 *}$ and Huong Hoang Nguyen LE $^{2}$ \\ ${ }^{1}$ Department of Financial Management, Faculty of Business Administration, Foreign Trade University, Hanoi, Vietnam \\ ${ }^{2}$ Department of Accounting and Auditing, Faculty of Accounting and Auditing, Foreign Trade University, Hanoi, Vietnam \\ *Corresponding author: hienbt@ftu.edu.vn
}

\begin{abstract}
Research purpose:

This study identifies factors affecting earnings management in the case of listed firms in Vietnam. Six factors, which include the number of management board members, the duality relationship chairman-director, auditor size, financial performance, firm size and financial leverage, are examined.

\section{Research motivation:}

Earnings management greatly affects the interests of shareholders in specific and the company in general. It erodes investor confidence in the stock market. Moreover, the goal set by the Government and the Ministry of Finance to "protect investors" is also not achieved. Among the published earnings management literature, there are few recent studies that examine the possible effects of earnings management technique on the developing market, determining whether earnings management occurs and whether there is an incentive to manipulate earnings. The research is motivated by the question of which factors affecting earnings management specifically in Vietnam.
\end{abstract}

\section{Research design, approach and method:}

Data of 147 manufacturing firms listed on Ho Chi Minh Stock Exchange from 2017 to 2019 is extracted from Finnpro platform, resulting in 441 firm-year observations. Panel data is processed using model of Jones (1991) and the hypothesis is tested using regression model with Eviews program.

\section{Main findings:}

The results show that two factors which are the duality relationship chairman-director and financial leverage have positive effects on earnings management. In contrast, two factors including the number of members in board of management and auditor size are negatively related to earnings management, while financial performance and firm size are not determinants of earnings managements.

\section{Practical/managerial implications:}

This study provides more evidence regarding earnings management and proposes some recommendations and implications to stakeholders about the transparency and quality of financial reporting. For example, companies should strengthen better corporate governance mechanisms; investors need to equip themselves with knowledge of accounting, financial analysis, and earnings management; and State agency should develop a roadmap for the "Investor Protection Law" to reduce the earnings manipulation behaviors.

Keywords: Earnings management, auditor size, financial performance, firm size, leverage, board characteristics

\section{INTRODUCTION}

Earnings management is a topic that researchers around the world such as Healy (1985), DeAngelo (1986), Jones (1991), Dechow and Sloan (1991), Friedlan (1994) have been interested in studying. Earnings management greatly affects the interests of shareholders in specific and the company in general. It erodes investor confidence in the stock market. Moreover, the goal set by the Government and the Ministry of Finance to "protect investors" is also not achieved. Much of the preceding literature has attempted to define and explain earnings management, and the literature has introduced numerous hypotheses for earnings management. Bamea (1976) defines earnings management behavior as an attempt to lower the cost of capital by minimizing the assessment of firm risk, which benefits shareholders by enabling management to communicate information useful for forecasting future earnings. Healy and Whalen's (1999) definition is the most widely used in the scholarly literature, concluding that earnings management is the deliberate use of judgment in financial reporting in order to deceive stakeholders about firm performance or to influence contractual outcomes. A more recent explanation has been raised by Buckmaster (2001), 
stating that earnings management was implemented to ensure the distribution of dividends in years of poor performance.

In Vietnam, the term earnings management has gradually been taken into consideration by researchers, creditors, investors, stockholders, and auditors. It directly reflects the quality of financial statements, where profits - one of the most important and highly concerned criteria is elucidated. Therefore, the credibility of financial reporting is heeded by both stockholders and administrators. While financial information has a great effect on stockholders and creditors, it is prepared and presented by administrators. The problem is administrators may not be stockholders and vice versa. Besides the benefit of stockholders, managers also find ways to increase management welfare. To this purpose, managers have opportunities to exert their authority on financial reports. In case they had the motivation to mislead users of financial statements, earnings management would stand a high chance of happening. Nguyen (2014) discovered that profits for selling additional stocks and shares in listed firms on the Vietnam Stock Exchange are overstated during the year of increased stock issuance. Earnings management improves with firm size, and audit quality of financial statements has no effect on earnings management. Tran (2014) identified the factors affecting earnings management in decreasing order as board independence $(61.7 \%)$, firm size $(15.53 \%)$, auditors $(14.56 \%)$, and financial leverage $(8.74 \%)$. Giap (2014) discovered that the chairmanship of the management board, the increased size of the management board, the increased ownership of the board of directors, and cash flow from operating activities all have a detrimental effect on earnings management.

Among the published earnings management literature, there are a few recent studies that identify factors affecting earnings management of listed companies, therefore, theoretical test of earnings management in the context of Vietnam and propose some recommendations to avoid earnings manipulation. This is a research gap, is a motivation to search for the impact of factors on earnings management of listed companies in the Vietnamese stock market. In addition, most of the previous studies used the model of Jones (1991), including studies in Vietnam (Nguyen, 2014). Therefore, this study inherits previous studies and uses the above model to conduct research.

This study is to identify factors affecting levels and its direction impact to earnings management. Through this study, users of listed companies' financial statements have a better understanding of how to make economic decisions. Additionally, several recommendations are made based on the findings for diminishing earnings management and improving financial data in publicly traded companies' financial statements. This study includes 5 sections:
Introduction, (2) Literature review on factors affecting earnings management, (3) Research methodology, (4) Research results and discussion, (5) Conclusions and recommendations

\section{LITERATURE REVIEW ON FACTORS AFFECTING EARNINGS MANAGEMENT}

\subsection{Concept of earnings management}

Earnings which also called net income, are the amount of profit that a company produces during a specific period, which is usually defined as a quarter (three calendar months) or a year. They are also the single most important item in financial statements and indicated as a signal that helps direct resource allocation in the capital market. Many formulas value a company by its future profits. The theoretical value of a company's stock presents the value of its future earning. Increased earnings represent an increase in company value, while decreased earnings signal a decrease in that value. As a result, management understands the importance of earnings in a company so, in many ways, they manipulate financial reports and learn how to manage earnings.

Earnings management is the use of accounting techniques to produce financial statements that present an overly positive view of a company's business activities and financial position. Earnings management takes advantage of how accounting rules are applied and creates financial statements that inflate or smooth earnings. Many accounting rules and principles require that a company's management make judgments in following these principles.

Earnings management may be also defined as "reasonable and legal management decision making and reporting intended to achieve stable and predictable financial results". Unlike fraud, earnings management encompasses the selection of accounting and estimates that conforms to the generally accepted accounting principles (GAAP). This means companies that practice earnings management would manage their earnings within the limits of accepted accounting procedures. However, certain monitoring mechanisms can prevent managers from inflating the earnings. However, earnings management is not indicated as illegal activities to manipulate financial statements. Financial statements containing profit management behavior will no longer reflect the real picture of the enterprise's production and business activities under normal conditions. It leads to the fact that most companies nowadays practice earnings management. Some cases do not cause great consequences, but some cases leave serious consequences.

\subsection{Some relevant theories}

\subsubsection{Agency theory}

Agency model is considered as one of the oldest theories in the literature of the management and economics (Daily et al., 2003; Wasserman, 2006). 
Agency theory discusses the problems that surface in the firms due to the separation of owners and managers and emphasizes on the reduction of this problem. This theory helps in implementing the various governance mechanisms to control the agents' action in the jointly held corporations. In a joint stock company, the ownership is held by individuals or groups in the form of stock and these shareholders (principals) delegates the authority to the managers (agents) to run the business on their behalf (Jensen \& Meckling, 1976; Ross, 1973), but the major issue is whether these managers are performing for the owners or themselves. Eisenhardt (1989) categorized the agency theory into two models such as the positivist agency model and principal-agent model. Both of these models are based upon the contractual relationship between the principal and agent but principal-agent model is more mathematical. Principalagent model explains that principals are risk-neutral and profit seekers, while agents are risk averse and rent seekers. Positive agency theory explains the causes of agency problem and the cost involved in it. This theory proposes two propositions. First proposition explains that if the outcome of the contract is incentive based, then the agents act in the favor of principal. Second, if the principal is having information about the agents, then the action of the agents will be disciplined.

Though agency theory is very pragmatic and popular, it still suffers from various limitations and this has been documented by many authors like Eisenhardt (1989), Shleifer and Vishny (1997) and Daily et al. (2003). The theory assumes a contractual agreement between the principal and agent for a limited or unlimited future period, where the future is uncertain. The theory assumes that contracting can eliminate the agency problem, but practically it faces many hindrances like information asymmetry, rationality, fraud and transaction cost. Shareholders' interest in the firm is only to maximize their return, but their role is limited in the firm. The roles of directors are only limited to monitor the managers and their further role is not clearly defined. The theory considers the managers as opportunistic and ignores the competence of the managers.

\subsubsection{Political costs theory}

Political costs are costs incurred by a business through a political act from an outside influence (State, union or community groups). These political costs affect the profits of the business, which leads to the ability of managers to limit political costs by taking action to adjust profits. The political cost hypothesis predicts that managers of corporations exposed to regulatory attention have incentives to manage earnings (e.g., by manipulating accounting accruals) in order to reduce the likelihood and/or the amount of these political costs. Managers, for example, may reduce earnings and related political costs by increasing reserves for estimated inventory obsolescence. Reduced political costs, in turn, enhance cash flows (e.g., through tax savings) which increase the firm's stock price. While higher stock prices increase stockholders' personal wealth, managers also benefit to the extent that their compensation is tied to share price (e.g., through stock options). Thus, in the case of political costs, earnings management can be viewed as aiding both stockholders and managers.

Traditionally, political cost researchers have assumed that large companies are more exposed to regulatory-imposed wealth transfers, as such firms are more politically sensitive. This size proxy for regulatory attention, however, oversimplifies the context of the wealth transfer setting. It ignores, for example, whether the regulatory behavior giving rise to such political costs varies with economic conditions, as Peltzman (1976) predicts. Empirical studies generally have supported Peltzman's hypothesis, especially in regard to mergerrelated antitrust activity (e.g., Eisner and Meier, 1990). Firm size and earnings management have a positive and significant relationship. (Nelson et al, 2002). Because, large-scale companies are often subject to the scrutiny of the capital market (investors, auditors, State Securities Commission, market analysts, etc). As a result, these companies tend to adjust their profits to avoid their disadvantage and to increase the positive impact on their company's image and brand in the market.

\subsection{Factors affecting earnings management}

\subsubsection{The number of members in management board}

According to the agency theory, the division of interests between managers and shareholders in listed companies is inevitable. In addition, managers are internal users, they have information that outside shareholders do not have or do not want (due to the high cost of obtaining it) due to asymmetric information theory. Therefore, they have many opportunities to manipulate earnings for a purpose. One of the measures used is the supervision mechanism through the board of management. This supervision is measured through the size of the board (the number of members on the board). Research results of authors around the world are not consistent. For example, according to Goodstein et al (1994), Jensen (1993), Dahiya and Yermack (2003), the smaller the board size (from 4 to 6 people), the more likely it is to make useful decisions in supervising the General Director (Director). Meanwhile, some other authors (Zahra and Pearce, 1989) argue that the small size of the management board is not effective in monitoring the activities of the General Director (Director).

\subsubsection{The duality relationship chairman-director}

The chairman of the board should be an independent person separate from the director/general director because if the two positions above are held by one person, it can easily lead to take advantage of assigned powers to make earnings managements and benefit them. Murhadi (2010) emphasized that the two titles of chairman and director/general director held by one person are positively correlated with the degree of earnings management. Rahman and Ali (2006) applied 
the Modified Jones (1995) model with cross-sectional data to study the effectiveness of the company's supervisory mechanism (the board of management, audit committee, and majority shareholder ownership) for earnings management. The authors found a positive relationship between the dual titles of director/general director and chairman of the board and the degree of earnings management. However, this relationship is not statistically significant, the reason can be explained here because the sample is small, so the representativeness of the population is not high.

\subsubsection{Auditor size}

According to agency theory, shareholders can use the supervision mechanism through independent audit to protect their interests. The quality of the independent auditors in particular and the audit firm in general can have a significant influence on the quality of the financial statements in general and the profit targets in particular. International auditing firms such as the Big4 are often seen as having an industry reputation and high audit quality. Therefore, listed companies that are audited by these auditing firms, their financial statements are considered to be of high quality. Krishnan (2003) explains that the audit firms in the Big4 group operate efficiently and with quality because, on the one hand, they have abundant financial resources, a team of professional independent auditors, knowledge welleducated, well-trained, on the other hand, they operate efficiently and with quality to protect their own reputation and brand. In addition, Becker et al. (1998) and Tran et al. (2020) explained that Big 4 audit firms positively align with earnings quality.

\subsubsection{Financial performance}

Return on Assets (ROA) is usually one of the key metrics to evaluate the business' performance and to make economic decisions accordingly. Sihasale (2001) examined the effect of the financial performance of the stock price of companies listed on the JSE. The result shows that jointly, ROE, ROA significantly influence stock prices. Earnings management was discovered by Change and Warfield (2005) by growing stock prices. Earnings management has been used to achieve a positive impact on the stock market (Chen et al., 2010, Charfeddine et al., 2013). According to Chen et al. (2006), the worse an entity's financial performance is, the more earnings management happens. Meanwhile, there is no relationship between financial performance and earnings management in the studies of Utami and Darmawan (2019) in Indonesia, Alves (2012) in Portugal, and Rahman and Ali (2006) in Malaysia. According to Nugroho (2001), ROA has a negative impact on stock prices. Many metrics, such as ROA, ROE, ROS, sales growth, and so on, are used to assess financial results.

\subsubsection{Firm size}

The size of a company is often used as a proxy for market details. Large companies may have more market access to information than small businesses. Large companies, according to Albrecth and Richardson (1990), have less incentive to smooth earnings than small firms. Lee and Choi (2002) have discovered that firm size influences a firm's ability to control earnings: smaller firms are more likely than larger firms to manage earnings to avoid disclosing losses. However, Moses (1987) finds evidence that large firms have a greater opportunity than small firms to smooth earnings. The greater the distinction between ownership and management, the more likely financial statements are prepared for management's benefit rather than for the benefit of financial statement users. According to Barto and Simko (2002), a large corporation is under a lot of pressure to overstate financial results to maintain a positive reputation with analysts. Since they want to make projected gains, listed companies use earnings management to deceive investors. The consistent proof is also found by Michaelson, James, and Charles (1995). Myers et al. (2007) gave empirical results of proving that a big firm states inaccurate profits Furthermore, a large company has a much higher volume of economic transactions and larger sums than a small firm. That is why when the accounting policies of large companies change, the profits are affected.

\subsubsection{Financial leverage}

The more credit a corporation has, the more likely it is to default and not be able to pay its debts, putting it at risk of going bankrupt. The stock market reacted negatively, with a decrease in stock share trading volume and stock share rate, resulting in a decrease in equity. Furthermore, there was a perception that having more credit meant the company was having trouble raising funds from stock share sales in the market, and that having more credit meant the company was not being taken seriously by investors or candidates looking to invest in stock shares.

Ulupui (2006) said that the debt-to-asset ratio had no impact on stock returns. This result differed from Sunarto's research. He said that the debt-to-asset ratio affected stock returns. It meant that a business with a low debt asset ratio would face less financial risk as the economy deteriorated, and it would have a better chance of making a lower profit when the economy was thriving.

Myers (1977) proposed that a company with risky debts will miss out on lucrative investment opportunities because customers have little incentive to spend while the majority of benefits go to creditors. Cai and Zhang (2011) used empirical evidence to back up their claim, showing that companies with higher debt ratios earn less potential investments. 


\section{RESEARCH METHODOLOGY}

\subsection{Research model}

Hypotheses are tested by utilizing model:

$$
\begin{aligned}
&\left|D A_{\mathrm{it}}\right|={ }_{0}+{ }_{1} \mathrm{BOARD}+{ }_{2} \mathrm{DUAL}+{ }_{3} \mathrm{AUDIT}+ \\
&{ }_{4} \mathrm{ROA}+{ }_{5} \mathrm{SIZE}+{ }_{6} \mathrm{LV}+\varepsilon
\end{aligned}
$$

Summary of variables in the model are presented in Table 1:

\begin{tabular}{|c|c|c|c|}
\hline $\begin{array}{l}\text { Name of } \\
\text { variables }\end{array}$ & $\begin{array}{l}\text { Type of } \\
\text { variables }\end{array}$ & Code & Measurement \\
\hline $\begin{array}{l}\text { Earnings } \\
\text { management }\end{array}$ & Dependent & $\mathrm{DA}$ & $\begin{array}{l}\text { DA is } \\
\text { measured by } \\
\text { the model of } \\
\text { Jones (1991) }\end{array}$ \\
\hline $\begin{array}{l}\text { The number } \\
\text { of members } \\
\text { in } \\
\text { management } \\
\text { board }\end{array}$ & Independent & BOARD & $\begin{array}{l}\text { The number of } \\
\text { people in } \\
\text { management } \\
\text { board }\end{array}$ \\
\hline $\begin{array}{l}\text { The duality } \\
\text { relationship } \\
\text { chairman- } \\
\text { director }\end{array}$ & Independent & $\begin{array}{l}\text { DUAL } \\
\end{array}$ & $\begin{array}{l}1 \text { if chair of } \\
\text { management } \\
\text { board cum a } \\
\text { director } \\
0 \text { if chair of } \\
\text { management } \\
\text { board is not a } \\
\text { director }\end{array}$ \\
\hline Auditor size & Independent & AUDIT & $\begin{array}{l}1 \text { if audited by } \\
\text { Big } 4 \text { auditors } \\
0 \text { if not audited } \\
\text { by Big } 4 \\
\text { auditors }\end{array}$ \\
\hline $\begin{array}{l}\text { Financial } \\
\text { performance }\end{array}$ & Independent & ROA & $\begin{array}{l}\text { Profit after tax/ } \\
\text { Total assets }\end{array}$ \\
\hline Firm size & Independent & SIZE & $\begin{array}{l}\text { Logarithms of } \\
\text { sales }\end{array}$ \\
\hline $\begin{array}{l}\text { Financial } \\
\text { leverage }\end{array}$ & Independent & LV & $\begin{array}{l}\text { Total } \\
\text { liabilities/ } \\
\text { Total assets }\end{array}$ \\
\hline
\end{tabular}

Table 1: Summary of variables in the model

Source: By the author (2021)

Thus, discretionary accruals should be first measured, the model of Jones (1991), which includes 2 equations, is used as follows:

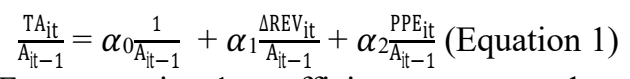

From equation 1, coefficients $0,{ }_{1}$ and ${ }_{2}$ are obtained to estimate DA (discretionary accrual) by using equation 2 as follows:

$$
\left|D A_{\mathrm{it}}\right| \mathrm{A}_{\mathrm{it}}=\frac{T \mathrm{~A}_{\mathrm{it}}}{\mathrm{A}_{\mathrm{it}}-1}-\alpha_{0} \frac{1}{\mathrm{~A}_{\mathrm{it}-1}}+\alpha \frac{\Delta \mathrm{REV} \mathrm{V}_{\mathrm{it}}}{\mathrm{A}_{\mathrm{it}-1}}+\alpha 2 \frac{\mathrm{PPE}_{\mathrm{it}}}{\mathrm{A}_{\mathrm{it}-1}}+\varepsilon \text { (Equation 2) }
$$

In which:

$\mid$ DAit $\mid$ is the absolute discretionary accrual of firm i for year $\mathrm{t}$

\subsubsection{Research hypothesis}

In order to investigate the effect of factors on earnings management in the case of listed firm in Vietnam, six hypotheses are proposed.

H1: The number of members in management board has a negative relationship with earnings management.

Agency theory suggests that, in addition to the salary and bonus mechanism for managers, another mechanism to protect the interests of shareholders is through the board of management. According to research by Persons (2006), the size of the management board has a negative relationship with earnings management.

H2: The duality relationship chairman-director has a positive relationship with earnings management.

In case, one person holds both a chair of management board and a director, this makes the conflicts of interests. Mulgrew and Forker (2006) found that if chair of management board also is a director, there is a high possibility to have earnings management.

H3: Auditor size has a negative relationship with earnings management.

Kinney and Martin (1994) reviewed nine related studies and concluded that there was a positive relationship between audit activities and net profits and assets of an auditee. Audit quality is evaluated basing on the auditor size of big 4 and non-big 4 and there is existence of relationship with auditor size and earnings management.

H4: Financial performance has a positive relationship with earnings management

For making economic decisions, investors base on the financial statements disclosed in the stock exchange such as stock price, audited financial statements and others. Charfeddine et al. (2003) found that in case of poor financial performance, stock prices and firm values reduce. That is why earnings management is arisen for keeping good reputation in the eyes of stakeholders.

H5: Firm size has a positive relationship with earnings management

Barto and Simko (2002) found that a large firm faces many pressures on overstating financial performance in order to have good images from analysts. Because of getting expected profits, this makes listed firms have earnings management for deceiving investors.

H6: Financial leverage has a positive relationship with earnings management

According to signaling theory, Watts and Zimmerman (1990) suggest that the choice of corporate financing can send signals to outside investors about corporate governance information. Therefore, it is possible that the company's managers have the goal of increasing profits to meet the wishes of creditors or reduce risks for the next loan agreement. 


\subsubsection{Data collection and analysis method}

The process of data collection is done as follows: First, select companies listed on the Ho Chi Minh Stock Exchange that have all the required published data to measure earnings management behavior. Second, to measure the factors affecting earnings management in the research model, data collection relies on annual reports, financial statements, management reports, and information extracted from Fiinpro platform. The Fiinpro Platform which launched in 2008 is the most comprehensive and in-depth database for the Vietnam market and provides the most up-to-date and reliable financial statements together with company profiles of both Vietnamese non-listed and listed firms. To analyze the quantitative data, this study applies descriptive and statistical summary of independent and dependent variables to find the average value, the largest The average number of listed manufacturing companies on HOSE audited by Big4 is about $24 \%$ of the companies. The average ratio of return on total assets of Vietnamese companies is 0.07 , the lowest is -0.47 and the highest is 0.42 . The average firm size of Vietnamese companies is 0.48 , the lowest is -2.44 and the highest is 12.09. The average ratio of total debt to total assets of Vietnamese companies is 0.47 , the lowest is 0.00 and the highest is 1.29 . value and the smallest of each study variable and the range of variance between those values. Next, correlation matrix is used to detect the relationships in each pair of research variables, focusing on the relationship between DA and each remaining research variable. Finally, OLS regression models were implemented by using Eviews 7.0 software to find the impact of factors on the DA.

\section{RESEARCH RESULTS AND DISCUSSION}

\subsection{Descriptive statistics}

The results of the descriptive statistics in Table 2 show that in Vietnam: The average number of management board members in Vietnam is about 7.22 persons. With a scale of 1 when the chairman is also director/general director and vice versa is a scale of 0 , the number of companies with a chairman cum director is $36 \%$.

\subsection{Correlation matrix}

The correlation analysis of variables presented in Table 3 shows the coefficients with appropriate correlation between variables. Moreover, most correlation coefficients between the independent variables are less than 0.8 , indicating no collinearity in the model.

Table 2: Descriptive statistics for variables included in the model

\begin{tabular}{|l|l|l|l|l|l|l|l|}
\hline & DA & BOARD & DUAL & AUDIT & ROA & SIZE & LV \\
\hline Mean & 0.02 & 7.22 & 0.36 & 0.24 & 0.07 & 0.48 & 0.47 \\
\hline Median & 0.00 & 7.00 & 0.00 & 0.00 & 0.05 & 0.09 & 0.49 \\
\hline Maximum & 3.36 & 13.00 & 1.00 & 1.00 & 0.42 & 12.09 & 1.29 \\
\hline Minimum & -1.96 & 3.00 & 0.00 & 0.00 & -0.47 & -2.44 & 0.00 \\
\hline Std. Dev. & 0.31 & 2.55 & 0.48 & 0.43 & 0.08 & 1.59 & 0.20 \\
\hline Skewness & 3.72 & 0.15 & 0.60 & 1.19 & -0.06 & 5.01 & -0.16 \\
\hline Kurtosis & 49.45 & 2.37 & 1.36 & 2.41 & 11.44 & 30.08 & 2.89 \\
\hline Jarque-Bera & 40656.57 & 9.02 & 75.90 & 109.91 & 1309.90 & 15318.77 & 2.15 \\
\hline Probability & 0 & 0 & 0 & 0 & 0 & 0 & 0 \\
\hline Sum & 8.25 & 3185.00 & 157.00 & 108.00 & 29.38 & 210.73 & 205.61 \\
\hline Sum Sq. Dev. & 42.48 & 2868.22 & 101.11 & 81.55 & 2.70 & 1116.63 & 17.63 \\
\hline Obs & 441 & 441 & 441 & 441 & 441 & 441 & 441 \\
\hline
\end{tabular}

(Source: Author, 2021)

Table 3: Correlation matrix for variables included in the model

\begin{tabular}{|c|c|c|c|c|c|c|c|}
\hline \multicolumn{8}{|l|}{ Correlation } \\
\hline Probability & DA & BOARD & DUAL & AUDIT & ROA & SIZE & $\mathbf{L V}$ \\
\hline \multirow{2}{*}{$\overline{\mathrm{DA}}$} & 1 & & & & & & \\
\hline & ----- & & & & & & \\
\hline \multirow[t]{2}{*}{ BOARD } & -0.4760 & 1 & & & & & \\
\hline & 0 & ---- & & & & & \\
\hline DUAL & 0.2586 & -0.2862 & 1 & & & & \\
\hline
\end{tabular}




\begin{tabular}{|l|l|l|l|l|l|l|l|}
\hline & 0 & 0 & ---- & & & & \\
\hline AUDIT & -0.3339 & 0.3641 & -0.3353 & 1 & & & \\
\hline & 0 & 0 & 0 & ----- & & & \\
\hline ROA & 0.0507 & -0.0943 & 0.0515 & 0.1071 & 1 & & \\
\hline & 0.2878 & 0.0477 & 0.2803 & 0.0245 & ----- & & \\
\hline SIZE & -0.0122 & 0.0265 & 0.0746 & -0.1395 & 0.3146 & 1 & \\
\hline & 0.7991 & 0.5785 & 0.1179 & 0.0033 & 0 & ---- & \\
\hline LV & 0.1176 & -0.0336 & 0.0974 & -0.0884 & -0.4022 & -0.1109 & 1 \\
\hline & 0.0135 & 0.4811 & 0.0409 & 0.0636 & 0 & 0.0198 & ---- \\
\hline
\end{tabular}

(Source: Author, 2021)

\subsection{Regression results}

Performing analysis of equation 1 according to OLS, the results obtained from Table 4 show that Adj Rsquared $=0.2278$, which means that $22.78 \%$ of the variation of the $\frac{T A_{i t}}{A_{i t}-1}$ variable is explained by the independent variables. It could be seen that the level of explanation of the equation 1 is not very high but remains acceptable (Prob $>\mathrm{F}=0.0000)$.

Table 4. Regression results of the equation 1

\begin{tabular}{|l|r|r|r|r|}
\hline Variable & \multicolumn{1}{|l|}{ Coefficient } & \multicolumn{1}{l|}{ Std. Error } & t-Statistic & \multicolumn{1}{l|}{ Prob. } \\
\hline C & 0.017421 & 0.009762 & 1.784558 & 0.075 \\
\hline 1/A_IT_1 & 0.012564 & 0.003703 & 3.392852 & 0.0008 \\
\hline REV/A_IT_1 & 0.114723 & 0.011331 & 10.12507 & 0 \\
\hline PPE/A_IT_1 & -0.05633 & 0.012104 & -4.65356 & 0 \\
\hline R-squared & 0.233035 & Mean dependent var & 0.01951 \\
\hline Adjusted R-squared & 0.22777 & S.D. dependent var & 0.133353 \\
\hline S.E. of regression & 0.117186 & Akaike info criterion & -1.44108 \\
\hline Sum squared resid & 6.001131 & Schwarz criterion & -1.40399 \\
\hline Log likelihood & 321.758 & Hannan-Quinn criter. & -1.42645 \\
\hline F-statistic & 44.25952 & Durbin-Watson stat & 1.777304 \\
\hline Prob(F-statistic) & 0 & & \\
\hline (Souce: Autho & &
\end{tabular}

(Source: Author, 2021)

Table 5. Regression results of the model

\begin{tabular}{|l|r|r|r|r|}
\hline \multicolumn{1}{|c|}{ Variable } & Coefficient & Std. Error & \multicolumn{1}{c|}{ t-Statistic } & \multicolumn{1}{c|}{ Prob. } \\
\hline C & 0.24784 & 0.059214 & 4.185526 & 0 \\
\hline BOARD & -0.04147 & 0.005327 & -7.78392 & 0.0001 \\
\hline DUAL & 0.054184 & 0.029329 & 1.847433 & 0.0654 \\
\hline AUDIT & -0.12696 & 0.03352 & -3.78754 & 0.0002 \\
\hline ROA & 0.156147 & 0.190553 & 0.81944 & 0.413 \\
\hline SIZE & -0.00614 & 0.008649 & -0.7099 & 0.4781 \\
\hline LV & 0.165642 & 0.071348 & 2.321617 & 0.0207 \\
\hline R-squared & 0.253458 & Mean dependent var & 0.018718 \\
\hline Adjusted R-squared & 0.243138 & S.D. dependent var & 0.310712 \\
\hline S.E. of regression & 0.270313 & Akaike info criterion & 0.237273 \\
\hline Sum squared resid & 31.71197 & Schwarz criterion & 0.302178 \\
\hline Log likelihood & -45.3186 & Hannan-Quinn criter. & 0.262875 \\
\hline F-statistic & 24.55789 & Durbin-Watson stat & 1.259918 \\
\hline \hline Prob(F-statistic) & 0 & & \\
\hline
\end{tabular}

(Source: Author, 2021) 


$$
\begin{aligned}
& \text { The full estimated equation } 1 \text { is: } \\
& \begin{array}{c}
\frac{\mathrm{TA}_{\mathrm{it}}}{\mathrm{A}_{\mathrm{it}-1}}=0.0125 * \frac{1}{\mathrm{~A}_{\mathrm{it}-1}}+0.1147 * \frac{\Delta \mathrm{REV} \mathrm{it}_{\mathrm{it}}}{\mathrm{A}_{\mathrm{it}-1}}-0.0563 \\
* \frac{\mathrm{PPE}}{\mathrm{A}_{\mathrm{it}-1}}+0.0174
\end{array}
\end{aligned}
$$

Using results from equation $1, \mathrm{DA}$ is estimated by equation 2 :

$$
\begin{gathered}
\left|D A_{\text {it }}\right| \mathrm{A}_{\text {it }}=\frac{\mathrm{TA}_{\mathrm{it}}}{\mathrm{A}_{\mathrm{it}-1}}-0.0125 * \frac{1}{\mathrm{~A}_{\mathrm{it}-1}}-0.1147 * \frac{\Delta \mathrm{REV}_{\mathrm{it}}}{\mathrm{A}_{\mathrm{it}-1}}+ \\
0.0563 * \frac{\mathrm{PPE}_{\mathrm{it}}}{\mathrm{A}_{\mathrm{it}-1}}
\end{gathered}
$$

The DA variable is used as the dependent variable to study the factors affecting the earnings management. The research model is as follows:

$$
\begin{gathered}
\left|D A_{\mathrm{it} t}\right|={ }_{0}+{ }_{1} \mathrm{BOARD}+{ }_{2} \mathrm{DUAL}+{ }_{3} \mathrm{AUDIT}+ \\
{ }_{4 \mathrm{ROA}}+{ }_{5} \mathrm{SIZE}+{ }_{6} \mathrm{LV}+\varepsilon
\end{gathered}
$$

Proceed to run OLS regression, results show statistical significance level $\mathrm{F}$ of the model $=0.000$ is less than 0.1 , inferring the model is statistically significant. Besides, the adjusted $\mathrm{R}^{2}$ had a value of $24.3 \%$, which means the independent variables explained $24.3 \%$ of the variation of the dependent variable. The Durbin-Watson coefficient $=1.2599$ is in the range from 1 to 3 , so it can be concluded that there is no autocorrelation between the variables in the model and the model is appropriate.

(1) The number of members in management board Table 5 also shows that the BOARD variable and the DA variable are negatively correlated (coefficient of the BOARD variable $=-0.041)$. Hypothesis $\mathrm{H} 1$ is accepted (prob. $=0.0001<0.1$ ). This result is consistent with agency theory and research results in the US (Persons, 2006); research in Australia (Xingzheng, 2011); developing countries such as Jordan stock exchange (Suzan et.al, 2012), Nigeria (Egbunike, 2015) and Vietnam (Samy et. al., 2016).

(2) The duality relationship chairman-director

The results of Table 5 show that these two variables have a positive relationship with each other (coefficient of DUAL variable $=0.054$ ) and the relationship is statistically significant (prob. $=0.0654<0.1$ ). In other words, hypothesis $\mathrm{H} 2$ is accepted. This result is consistent with the study in the Malaysian stock market (Rahman and Ali, 2006) and the study in the Jordan market (Suzan Abed et al., 2012).

(3) Auditor size

As Table 5 shows, it seems that companies that are Big4 audit clients have lower adjusted earnings than others. In other words, the auditor size variable (AUDIT) has a negative relationship with the variable DA and this relationship is statistically significant (prob. $=0.0002<0.1$ ). Therefore, hypothesis H5 is accepted. This research result is consistent with research results of some developing countries such as: Malaysia (Johl et al., 2007) and Indonesia (Rifki Zulkarnain, 2014).

(4) Financial performance

The research results show that there is a positive correlation between the financial performance (ROA variable) and earnings management (DA variable), shown in the regression coefficient of 0.156 shown in Table 5. However, this relationship is not statistically significant (prob. $=0.413>0.1$ ). In other words, hypothesis H4 is not accepted. This result is similar to the study in Iran (Seyed, 2015); and in Vietnam (Samy Essa, 2016).

(5) Firm size

As Table 5 shows, it seems that companies that the SIZE variable has a negative relationship with the variable DA, but this relationship is not statistically significant (prob. $=0.4781>0.1$ ). Hypothesis H5 is not accepted. This research result is consistent with research results in Nigeria (Egbunike, 2015) and Iran (Farzaneh, 2006).

(6) Financial leverage

With the research results shown in Table 5, the evidence supports the hypothesis that the larger the financial leverage, the larger the earnings management of the enterprise (due to the regression coefficient associated with the variable $\mathrm{LV}=0.1656$ ). and (prob. $=0.0207<0.1)$. This also means that hypothesis H6 is accepted. The above results can be explained by countries around the world such as Othman (2006), Moieira (2007) and Prevost (2008).

\section{CONCLUSIONS AND RECOMMENDATIONS}

\subsection{Conclusions}

This study studies on the factors affecting earnings management in the case of listed firms in Vietnam. Literature review was based on four fundamental theories which are agency theory, information asymmetry theory, signaling theory and political cost theory. Accordingly, by using a panel data including 147 selected manufacturing listed firms in Vietnam, the research results show that, (i) there exists a phenomenon of earnings management in companies listed on Vietnam's stock market; (ii) the duality relationship chairman-director and the financial leverage is proportional to the phenomenon of earnings management; (iii) the smaller the size of the board of directors and the independent auditors, the more earnings management will be; (iv) financial performance and firm size have no effect on earnings management phenomenon.

\subsection{Recommendations}

\subsubsection{Recommendations for stakeholders}

Investors are one of the main users of information from the financial statements of listed companies. Investors should be aware that the figures in the financial statements have been adjusted by the managers of listed companies. Therefore, investors need to equip themselves with knowledge of accounting, 58 financial analyses, securities analysis, portfolio management, risk management, market analysis, especially the knowledge about the earnings management 
behavior of listed joint stock companies. From there, investors can predict risks and be more cautious in choosing a portfolio of investment stocks. To do so, universities and academies should provide knowledge about earnings management and corporate governance in the curriculum of Accounting, Auditing, Finance major. In addition, investors should gain knowledge through self-studying by using internet, books, etc. Investors should also carefully review and maintain a skeptical attitude towards stock symbol that disclose information, especially financial statements, late. Because, if the company operates normally, and all arising economic and financial transactions are reflected in the accounting books, the preparation of financial statements is very fast, especially with the support of accounting software today. Meanwhile, the Accounting Law stipulates the maximum time limit for submitting financial statements is 90 days from the end of the financial year. The question is, "What do companies do during that 90 -day period that makes them file late financial statements?" It is worth bearing in mind whether there is ambiguity and confusion in the preparation and presentation of financial statements or not.

\subsubsection{Recommendations for listed firms in Vietnam}

To keep earnings managements to a minimum, management awareness is critical, as transparency of information is maintained only when the leaders of each business understand how to respect and honor it first. Enterprises should approach corporate governance from the "bottom-up", that is, they should manage their operations effectively by focusing on the company's actual specific activities. The executive board listens to, shares, and synthesizes the opinions of all individuals and groups within the unit. This approach assists business leaders in developing an "open" mindset. The ultimate target is to assist in the public disclosure of information in general, and financial information in particular, in an honest, transparent, and complete manner. Management boards of publicly traded companies must always remember that information transparency is a requirement, not a requirement. Information plays a significant role in the upward (downward) movement of stock prices in the stock market. Specific for each ticker, positive or negative news will cause the price of this stock to increase or decrease significantly for multiple consecutive sessions. For business leaders who are ethical, follow the law, and work for the benefit of shareholders, information disclosure and transparency are ways to earn the trust of shareholders, mobilize capital, and develop the business.

\subsubsection{Recommendations for audit firm}

In order to improve audit quality, audit firms must prioritize resource and workforce development. Comprehensive education and training programs must be developed that emphasize the importance of current audit knowledge, study cases, and technology. Career paths must be carefully planned in order to demonstrate the company's affection, trust, and care for each employee which will increase employee loyalty and effectiveness. Additionally, in addition to enhancing audit quality through increased resources and workforce, audit firms in Vietnam may place a greater emphasis on developing quality control systems, audit procedures, and risk assessment processes. Moreover, audit firm should also make effort to encourage employee to join the Vietnam Association of Certified Public Accountants (VACPA) as the association requires research and comprehensive guidelines to assist auditors in making sound professional judgments and conducting effective audits.

\subsection{Implications to State agency}

Vietnam scored 54 points on the World Bank's Business Environment 2020 report's index of minority investor protection. This index is slightly higher than the Asia-Pacific region's average (53.4 points). Additionally, due to Vietnam's lack of information transparency, stock prices in general and individual stocks in specific do not accurately reflect previously published information. As a result, the competent state agency should develop a roadmap for the passage of the "Investor Protection Law"; once the law is clear and specific sanctions are in place, the board of directors' compliance will be evaluated. As a result, it contributes to the reduction of earnings management behavior.

\section{REFERENCES}

[1]. Aljifri, K (2007), "Measurement and Motivations of Earnings management: A Critical Perspective", Journal of Accounting - Business \& Management, Vol.14, 75-95.

[2]. Bamea, A. J. (1976). Classificatory Smoothing of Income With Extraordinary Items. The Accounting Review, Vol.51, No.1.

[3]. Barton, J., and Paul J. Simko, P.J. (2002), The Balance Sheet as an Earnings Management Constraint. The Accounting Review, 77(1), 1-27.

[4]. Bartov, E (1993), "The timing of asset sales and earnings manipulation", The Accounting Review, Vol. 68, No 4, 40-55.

[5]. Bartov, E., D. GiVol.y, and C. Hayn (2002), "The rewards to meeting or beating earnings expectations", Journal of Accounting and Economics, Vol. 33, No 2, 173-204.

[6]. Baker, T., D. Collins and A. Reitenga (2003), "Stock-option compensation and earnings management incentives", Journal of Accounting, Auditing and Finance, Vol 8, 557-582.

[7]. Becker, C. M. Defond J. Jiambalvo and K. Subramanyam (1998), "The effect of audit quality on earnings management", Contemporary Accounting Research, Vol. 15, 1-24. 
[8]. Buckmaster, D. (2001). Development of the income smoothing literature 1893-1998: A focus on the United States. Oxford, UK: Elsevier Science Ltd.

[9]. Dahiya, S., \& Yermack, D. (2003). Litigation exposure, capital structure and shareholder value: the case of Brooke Group. Journal of Corporate Finance, 9(3), 271-294.

[10]. Daily, C. M., Dalton, D. R., \& Cannella Jr, A. A. (2003). Corporate governance: Decades of dialogue and data. Academy of management review, 28(3), 371-382.

[11]. Dalton, D. R., Daily, C. M., Ellstrand, A. and Johnson, J (1998), "Board composition, leadership structure, and financial performance: meta-analytic reviews and research agenda", Strategic Management Journal, Vol. 19, 69-90.

[12]. Davidson, R. Goodwin-Steward, J. and Kent, P. (2005), "Internal governance structures and earnings management", Accounting and Finance, Vol. 45, 241-267.

[13]. DeAngelo, L.E (1986), “Accounting Numbers as Market Valuation Substitutes: A Study of Management Buyouts of Public Stockholders", The Accounting Review, Vol. 61, No. 3, 400-420.

[14]. Egbunike Amaechi Patrick, Ezelibe Chizoba Paulinus, Aroh Nkechi Nympha (2015), "The Influence of Corporate Governance on Earnings Management Practices: A Study of Some Selected Quoted Companies in Nigeria", American Journal of Economics, Finance and Management, Vol. 1, No.5, 482-493.

[15]. Erickson, M., M. Hanlon, and E. L. Maydew (2006), "Is there a link between executive equity incentives and accounting fraud?", Journal of Accounting Research, Vol. 44, 113-144.

[16]. Eisenhardt, K. M. (1989). Agency theory: An assessment and review. Academy of management review, 14(1), 57-74.

[17]. Eisner, M. A., \& Meier, K. J. (1990). Presidential control versus bureaucratic power: Explaining the Reagan revolution in antitrust. American Journal of Political Science, 269-287.

[18]. Friedlan, J. M. (1994). Accounting choices of issuers of initial public offerings. Contemporary accounting research, 11(1), 1-31.

[19]. Giap, T. L. (2014), Relationship of corporate governance and earnings management of listed firms on Ho Chi Minh Stock Exchange. Master study, Ho Chi Minh University of Economics.

[20]. Goodstein, J., Gautam, K., \& Boeker, W. (1994). The effects of board size and diversity on strategic change. Strategic management journal, 15(3), 241250.

[21]. Guidry, Leone and Rock (1999), "Earnings-based bonus plans and earnings management by businessunit managers", Journal of Accounting and Economics, Vol. 26, 113-142.
[22]. Healy P.M (1985), "The Effect of Bonus Schemes on Accounting Decisions," Journal of Accounting and Economics, Vol. 7, 85-107.

[23]. Healy, P, Wahlen, J (1999), "A review of the earnings management literature and its implications for standard setting", Accounting Horizons, Vol 13, 365-383.

[24]. Iatridis, G., and Kadorinis, G (2009), "Earnings management and firm financial motives: A financial investigation of UK listed firms", International Review of Financial Analysis, Vol. 18, No.4, 164173.

[25]. Jensen, MC and Meckling (1976), “Theory of Firm: Managerial Behaviour, Agency Costs and Ownership Structure", Journal of Financial Economics, Vol. 3, 305-350.

[26]. Johnson, D. (1998) Applied Multivariate Methods for Data Analysis. Duxbury Press, Pacific Grove, 407

[27]. Johl, S., Jubb, C., and Houghton, K (2007), "Earnings management and the audit opinion: evidence from Malaysia", Managerial Accounting Journal, Vol.22, No.7, 688-715.

[28]. Jones, J. J. (1991). Earnings management during import relief investigations. Journal of Accounting Research, 29(2), 193-228. https://doi.org/10.2307/2491047

[29]. Kothari, S.P., Lcone, A.J., and Wasley, C.E (2005), "Performance-Matched Discretionary Accruals", Journal of Accounting and Economics, Vol. 39, 163-197.

[30]. Krishnan, G. V (2003), "Does big 4 auditor industry expertise constrain earnings management", Accounting Horizons, Vol. 17, 1-16.

[31]. Moeira, J. A. and Pope, P. F (2007), "Earnings management to avoid losses: a cost of debt explanation", Working paper, Lancaster University.

[32]. Mulgrew, M., \& Forker, J. (2006). INDEPENDENT NON-EXECUTIVE DIRECTORS AND EARNINGS MANAGEMENT IN THE UK. Irish Accounting Review, 13(2).

[33]. Murhadi, W. R. (2010). Good Corporate Governance and Earning Management Practices: An Indonesian Cases. Retrieved August 16, 2021 (actual access date), from: SSRN: https://ssrn.com/abstract=1680186 or http:// dx.doi.org/10.2139/ssrn.1680186 http://dx.doi.org/10.2139/ssrn.1680186

[34]. Nelson, M. W., J, A. Elliott, and R. L. Tarpley (2002), "Evidence from Auditors about Managers" and Auditors"e Earnings Management Decisions", The Accounting Review, Vol 77 (Sulement), 175202.

[35]. Nguyen, T. P. (2014), Relationship between financial statement disclosure and earnings management of listed firms in Vietnam. Master study, Ho Chi Minh University of Economics. 
[36]. Peltzman, S. (1976). Toward a more general theory of regulation. The Journal of Law and Economics, 19(2), 211-240.

[37]. Persons, O.S (2006), "Corporate Governance and Non-Financial Reporting Fraud", The Journal of Business and Economic Studies, Vol.12, No. 1, pp 27-40.

[38]. Prevost, A. K., Skousen, C. J., and Rao, R. P (2008), "Earnings Management and the Cost of Debt, Working paper, Ohio State University, Department of Finance, Stillwater.

[39]. Pincus, M., and Rajgopal, S (2002), "The interaction of accrual management and hedging: Evidence from oil and gas firms", The Accounting Review, Vol. 71, 127-160.

[40]. Pham Thi Bich Van (2017), "Earnings management before and after the issuance of shares on the Vietnam stock market", Journal of Economic Science, No. 01/2017, 98-110.

[41]. Rahman, R. A., \& Ali, F. H. M. (2006). Board, audit committee, culture and earnings management: Malaysian evidence. Managerial auditing journal.

[42]. Roychowdhury, S (2006), "Earnings Management through Real Activities Manipulation, Market Performance", Journal of Accounting and Economics, Vol. 42, 335-370.

[43]. Rifki Zulkarnain, Indra Wijaya Kusuma (2014), "The effect of leverage, firm size, independent commissioner and reputation on earnings management: Empirical Study on Manufacturing Companies Listed in the Indonesian Stock Exchange 2010-2012"

[44]. Samy Essa, Rezaul Kabir and Huy Tuan Nguyen (2016), "Does corporate governance affect earnings management? Evidence from Vietnam", University of Twente The Netherlands
[45]. Suzan Abed, Ali Al-Attar and Mishiel Suwai dan (2012), "Corporate Governance and Earnings Management: Jordanian Evidence", International Business Research, Vol. 5, No. 1, 216-115.

[46]. Subramanyam, K (1996), "The Pricing of Discretionary Accruals", Journal of Accounting and Economics, pp 249-281.

[47]. Tran, T. M. T. (2014), Factors affecting earnings management of listed firms on Ho Chi Minh Stock Exchange. Master study, Ho Chi Minh University of Economics.

[48]. Tran, Q. T., Lam, T. T., \& Luu, C. D. (2020). Corporate governance and earnings management: A study of Vietnamese listed banks. The Journal of Asian Finance, Economics, and Business, 7(12), 389-395. https://doi.org/10.13106/jafeb.2020.vol7.no12.389

[49]. Shleifer, A., \& Vishny, R. W. (1997). A survey of corporate governance. The journal of finance, 52(2), 737-783.

[50]. Ulupui, I.G.K.A. (2006). Analisis Pengaruh Rasio Likuiditas, leverage, Aktivitas dan Profitabilitas Terhadap Returns Saham. Universitas Udayana.

[51]. Watts, R. L and Zimmerman, J. L (1990), "Positive Accounting Theory: A Ten-Year Perspective", Accounting Review, Vol. 65, No. 1, 131-156.

[52]. Wasserman, N. (2006). Stewards, agents, and the founder discount: Executive compensation in new ventures. Academy of Management Journal, 49(5), 960-976.

[53]. Zahra, S., and Pearce, J (1989), "Boards of Directors and Corporate Financial Performance: A Review and Integrative Model", Journal of Management, Vol.15, 291-334. 